Supporting Information :

\title{
Photoreactivity and enhanced mechanical properties and water stability in polysaccharide-based films using vanadium ion coordination
}

\author{
Carina Haddad, E.A.Kalani D. Edirisinghe, Hope M. Brown and Alexis D. Ostrowski* \\ Department of Chemistry and Center for Photochemical Sciences, Bowling Green State University, Bowling Green, \\ Ohio 43403, United States
}

Corresponding author: Alexis D. Ostrowski

alexiso@bgsu.edu 
Tables:

Table S1. Table showing the different conditions at which the films were prepared and the properties of the obtained film.

\begin{tabular}{|c|c|c|c|c|}
\hline Batch \# & $\begin{array}{l}\mathrm{V}(\mathrm{V}) \\
\text { concentration } \\
(\mathrm{mM})\end{array}$ & $\begin{array}{l}\text { Pectin:chitosan:glycerol mass } \\
\text { ratio }\end{array}$ & $\begin{array}{l}\text { Soaking } \\
\text { time } \\
\text { (minutes) }\end{array}$ & $\begin{array}{l}\text { Film } \\
\text { properties/observation }\end{array}$ \\
\hline \multirow[t]{8}{*}{1} & 1 & \multirow[t]{8}{*}{$1: 1: 0.5$} & \multirow[t]{8}{*}{5} & Chitosan precipitated out \\
\hline & 5 & & & Chitosan precipitated out \\
\hline & 10 & & & Chitosan precipitated out \\
\hline & 15 & & & Chitosan precipitated out \\
\hline & 20 & & & Moderate stiffness \\
\hline & 25 & & & Increased stiffness \\
\hline & 30 & & & Increased stiffness \\
\hline & 50 & & & Very stiff \\
\hline \multirow[t]{4}{*}{2} & \multirow[t]{4}{*}{20} & \multirow[t]{4}{*}{ 1:1:0.5 } & 0.5 & Weak and soft \\
\hline & & & 1 & $\begin{array}{l}\text { Increased stiffness but } \\
\text { not good enough }\end{array}$ \\
\hline & & & 5 & $\begin{array}{c}\text { Increased but moderate } \\
\text { stiffness }\end{array}$ \\
\hline & & & 10 & Very stiff \\
\hline \multirow[t]{5}{*}{3} & \multirow[t]{5}{*}{20} & 1:1:0.5 & \multirow[t]{5}{*}{5} & Not elastic/ductile \\
\hline & & $1: 1: 2$ & & $\begin{array}{c}\text { Increased } \\
\text { elasticity/ductility but not } \\
\text { enough }\end{array}$ \\
\hline & & $1: 1: 3$ & & $\begin{array}{c}\text { Increased } \\
\text { elasticity/ductility but not } \\
\text { enough }\end{array}$ \\
\hline & & $1: 1: 4$ & & $\begin{array}{c}\text { Increased } \\
\text { elasticity/ductility, good } \\
\text { for mechanical testing }\end{array}$ \\
\hline & & $1: 1: 5$ & & Too elastic \\
\hline
\end{tabular}

Table S2. Table showing solubility percentages for 5 different $V(V)$ films and the calculated solubility $\%$ average.

\begin{tabular}{|c|c|c|c|c|c|c|}
\hline Sample \# & $\mathbf{1}$ & $\mathbf{2}$ & $\mathbf{3}$ & $\mathbf{4}$ & $\mathbf{5}$ & $\begin{array}{c}\text { Average } \\
\text { 士SD }\end{array}$ \\
\hline $\begin{array}{c}\text { Initial dry weight of } \\
\text { film, } \mathrm{W}_{\mathrm{i}}\end{array}$ & 0.0143 & 0.0144 & 0.0132 & 0.0141 & 0.0151 & \\
\hline $\begin{array}{c}\text { Final dry weight of } \\
\text { film, } \mathrm{W}_{\mathrm{f}}\end{array}$ & 0.0110 & 0.0110 & 0.0107 & 0.0109 & 0.0118 & \\
\hline $\begin{array}{c}\text { Solubility } \\
\%=\frac{(W i-W f)}{W_{i}} \mathrm{x} 100\end{array}$ & 23.1 & 23.6 & 18.9 & 22.7 & 21.8 & $22.0 \pm 1.7$ \\
\hline
\end{tabular}




\section{Figures:}

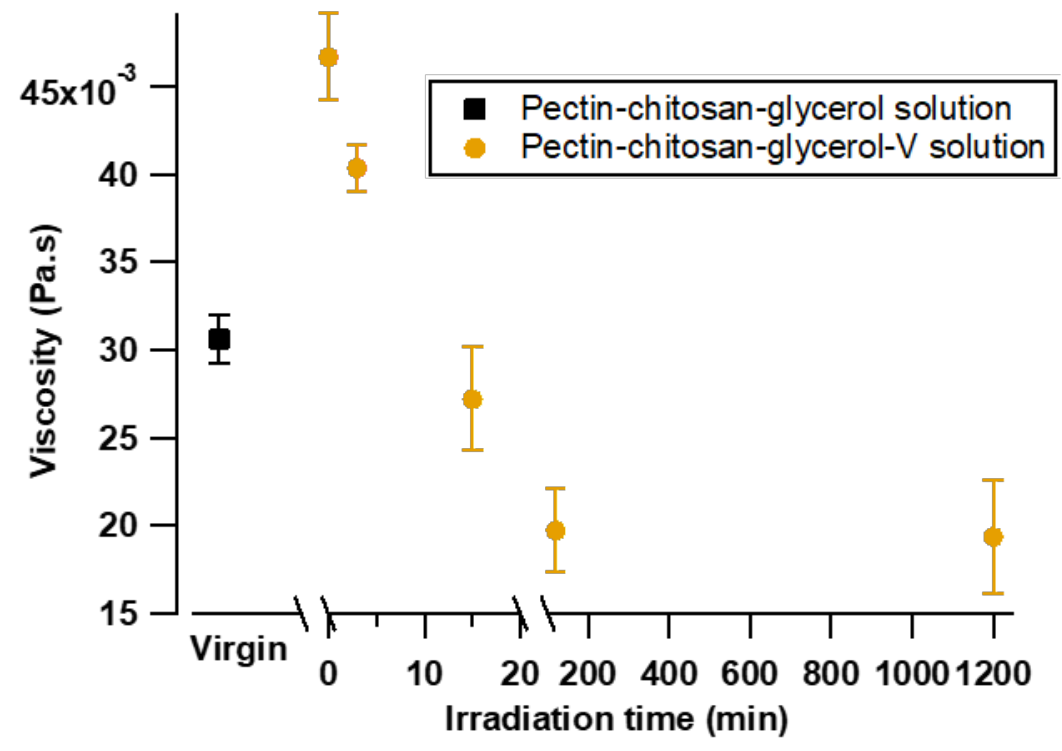

Figure S1. Changes in viscosity of a solution containing pectin, chitosan, and glycerol before and after adding vanadium metal and upon irradiation of the metal containing solution with $405 \mathrm{~nm} \operatorname{LED}\left(145 \mathrm{mw} / \mathrm{cm}^{2}\right)$ for increasing periods of time.
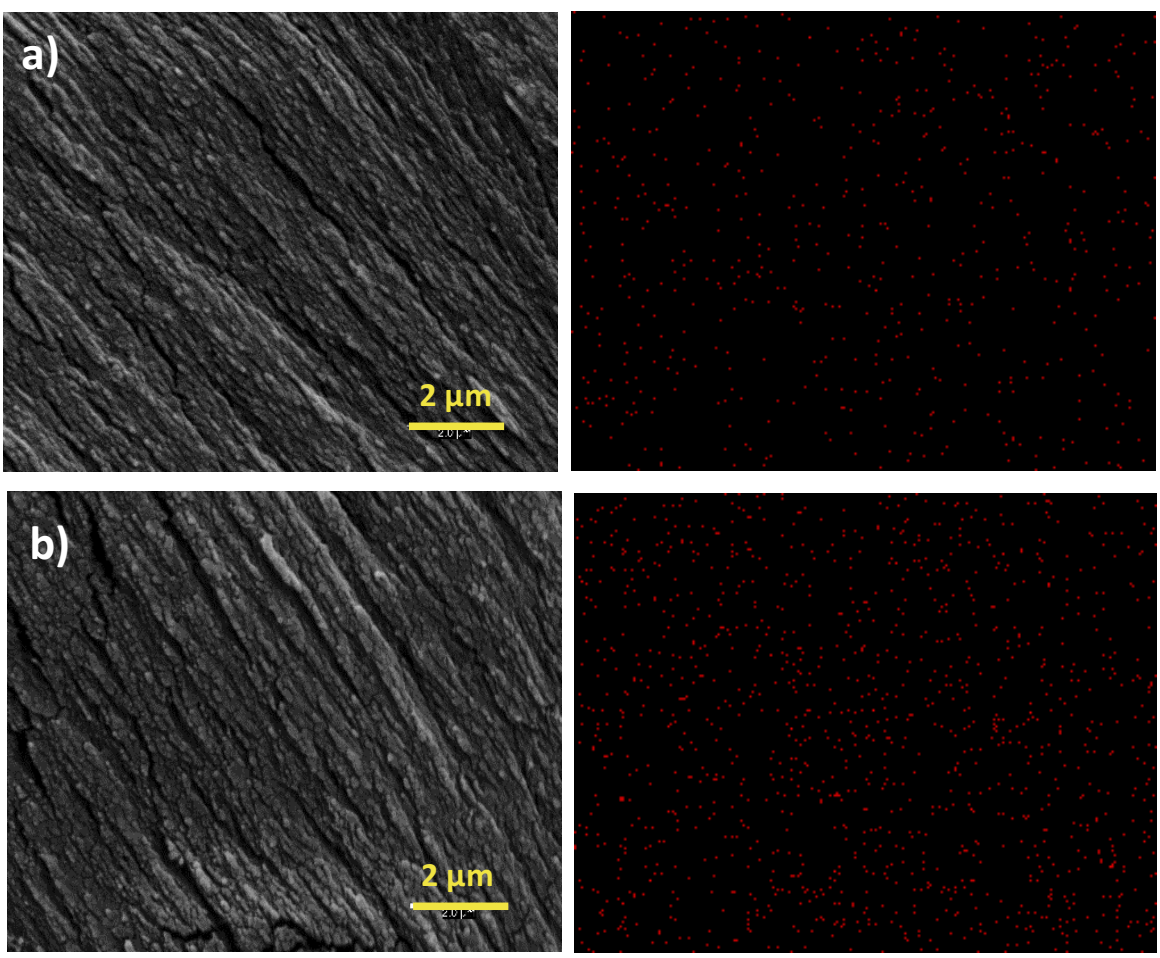

Figure S2. Left: Electron micrographs showing the cross-section of a) $V(V)$ film irradiated for $2 \mathrm{~min} \mathrm{~b}) 2$ hours using $405 \mathrm{~nm}$ LED $\left(145 \mathrm{~mW} / \mathrm{cm}^{2}\right)$. Right: Mapping of $\checkmark$ element inside the films. 


\section{Swelling and solubility tests of $\mathrm{V}(\mathrm{V})$ films:}

The air-dried films were cut into small rectangular strips $(\sim 30.00 \mathrm{~mm} \times 12.50 \mathrm{~mm})$ and weighed. For the swelling study, 3 strips were soaked in $7 \mathrm{~mL}$ of deionized water in a $47 \mathrm{~mm}$ diameter petri dish and allowed to swell for different times at room temperature. Fully swollen films were carefully wiped with a Kimwipe and weighed again. The swelling ratio of each film was calculated using equation 1: Swelling $\%=\frac{(W w-W d)}{W d} \times 100(1)$, where $\mathrm{W}_{\mathrm{w}}$ is the weight of the water saturated film and $\mathrm{W}_{\mathrm{d}}$ is the weight of the initial air-dried film.

For the solubility test, 5 films were soaked each in $50 \mathrm{~mL}$ of deionized water in 125 Erlenmeyer flasks. The flasks were placed on an agitator for 24 hours. The films were removed, and air dried for 3 days. The solubility percentage was calculated using equation 2: Solubility $\%$ $=\frac{(W i-W f)}{W i} \times 100(2)$, where $\mathrm{W}_{\mathrm{i}}$ is the initial dry weight of film and $\mathrm{W}_{\mathrm{f}}$ is the final dry weight of the film.

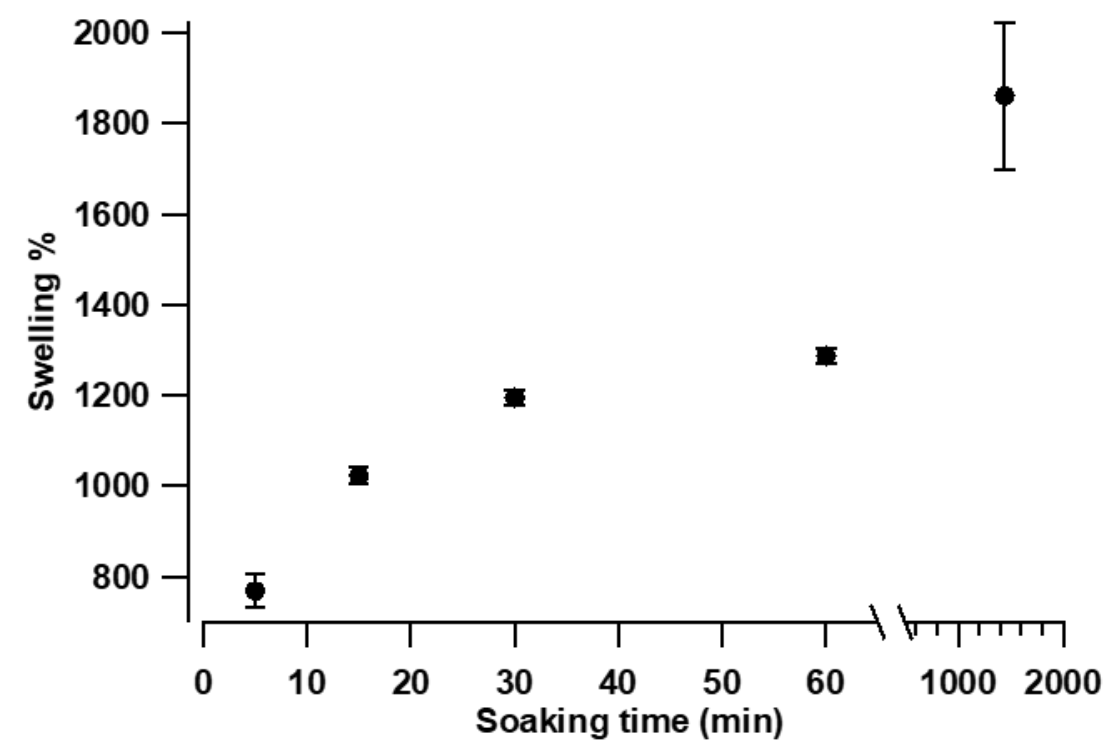

Figure S3. Changes of swelling \% of V(V) film with increasing soaking times in water. 


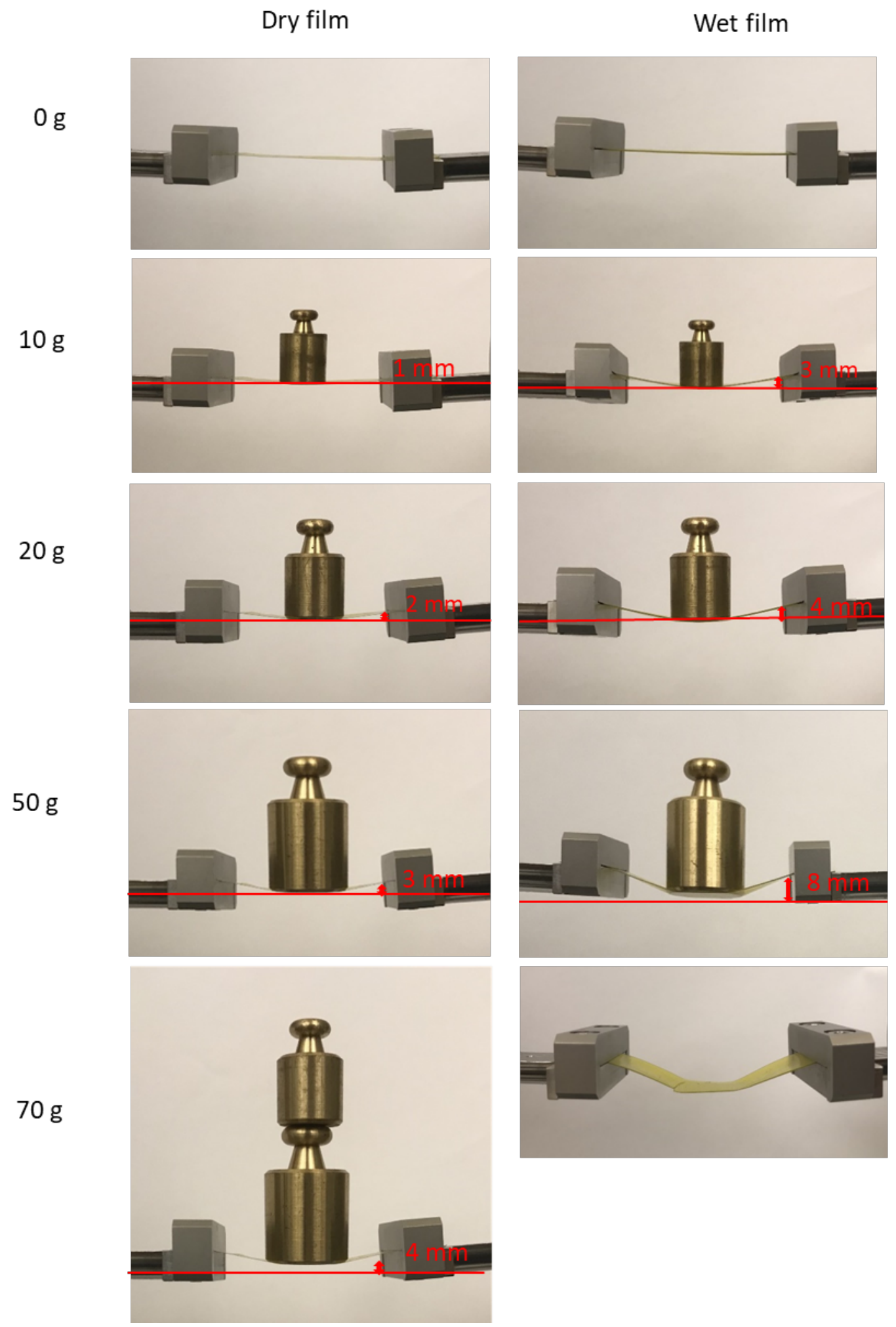

Figure S4. Images showing how dry vs. wet V(V) films bend downward when different weights are placed on top of them. 
a)

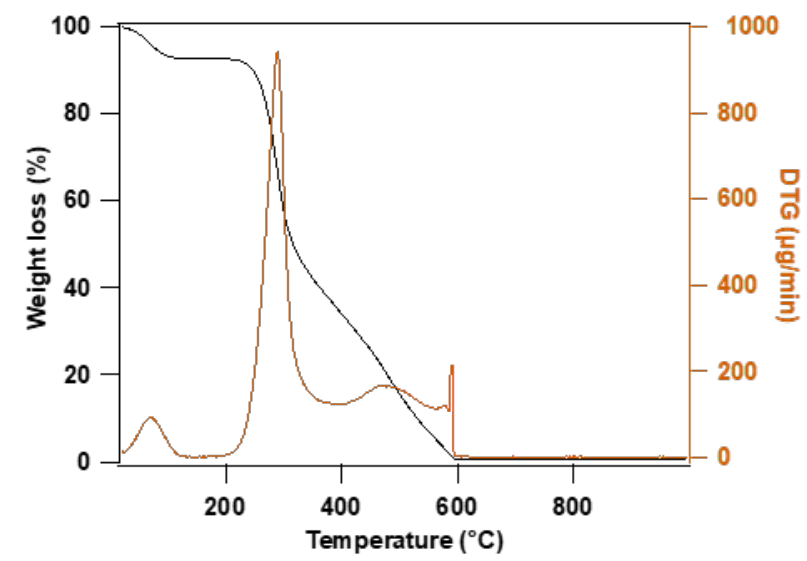

b)

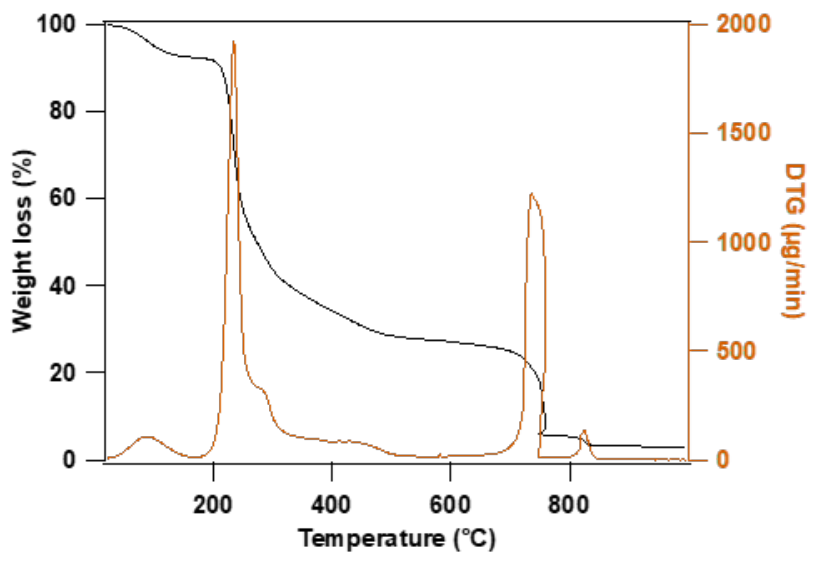

Figure S5.TGA and DTG patterns of a) chitosan and b) pectin.

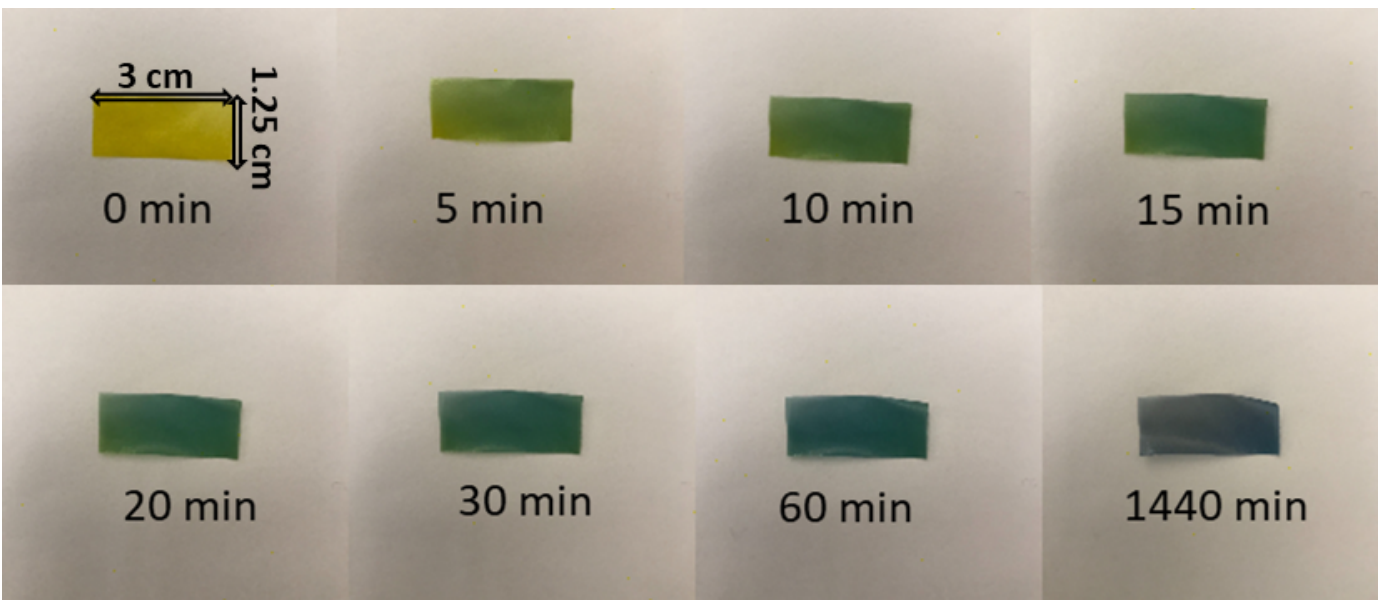

Figure S6. Changes in color of $\mathrm{V}(\mathrm{V})$ film upon irradiation with $405 \mathrm{~nm}$ LED source $\left(145 \mathrm{~mW} / \mathrm{cm}^{2}\right)$ for increasing periods of time. 


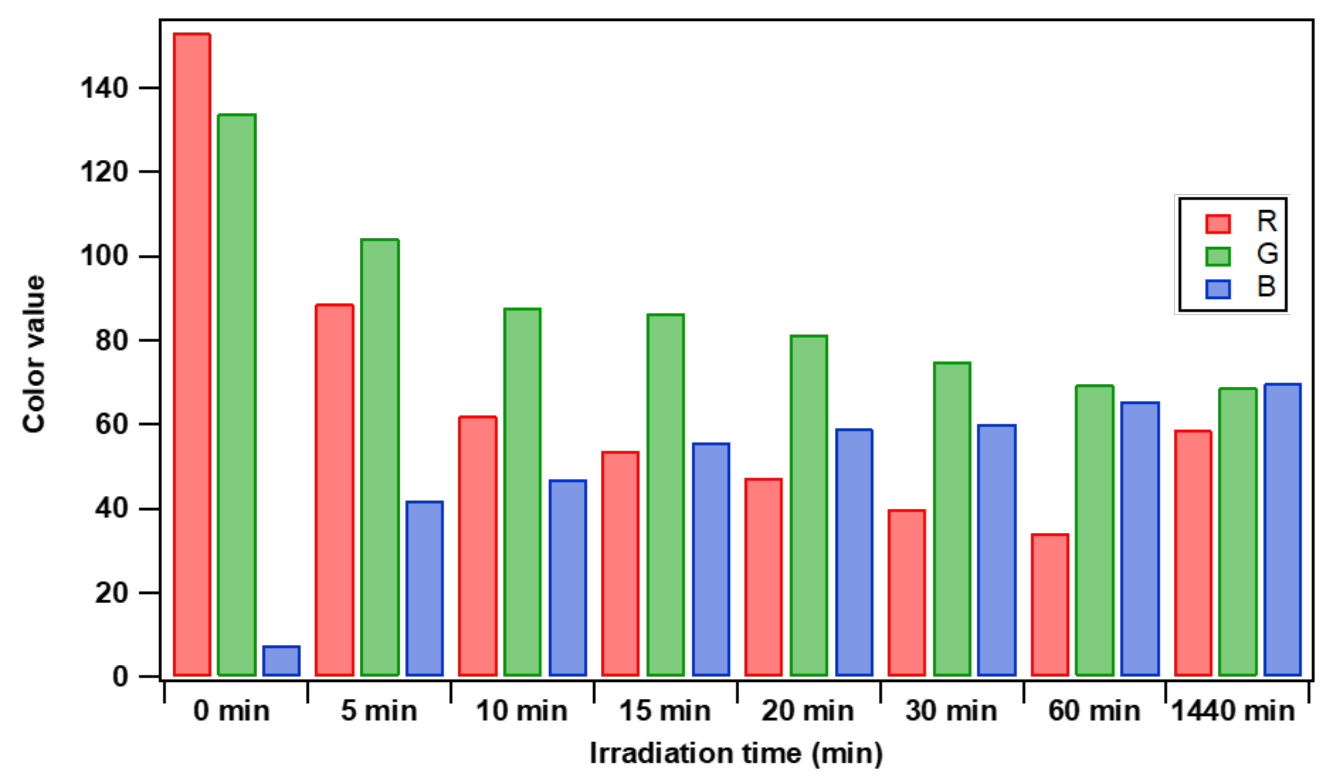

Figure S7. Plot of Average R, G, B color analysis values as determined by ImageJ for a V(V) film irradiated with 405 $\mathrm{nm}$ LED $\left(145 \mathrm{~mW} / \mathrm{cm}^{2}\right)$ for increasing periods of time.

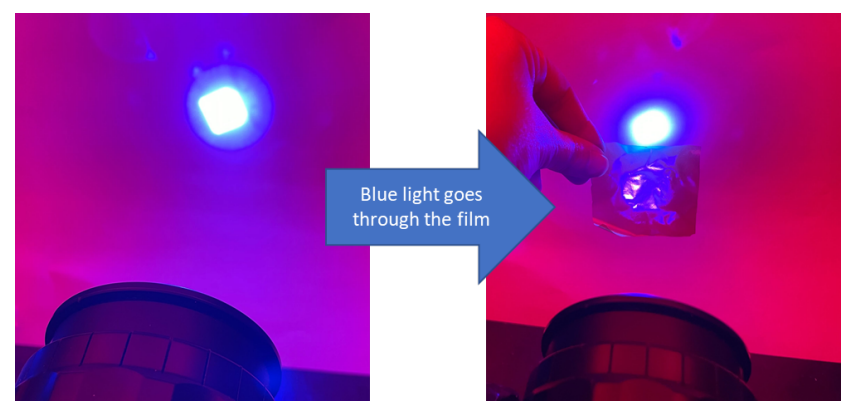

Figure S8: Photographs showing that the high-intensity LED light using for irradiation is able to fully penetrage the thin $\mathrm{V}(\mathrm{V})$ chitosan pectin films

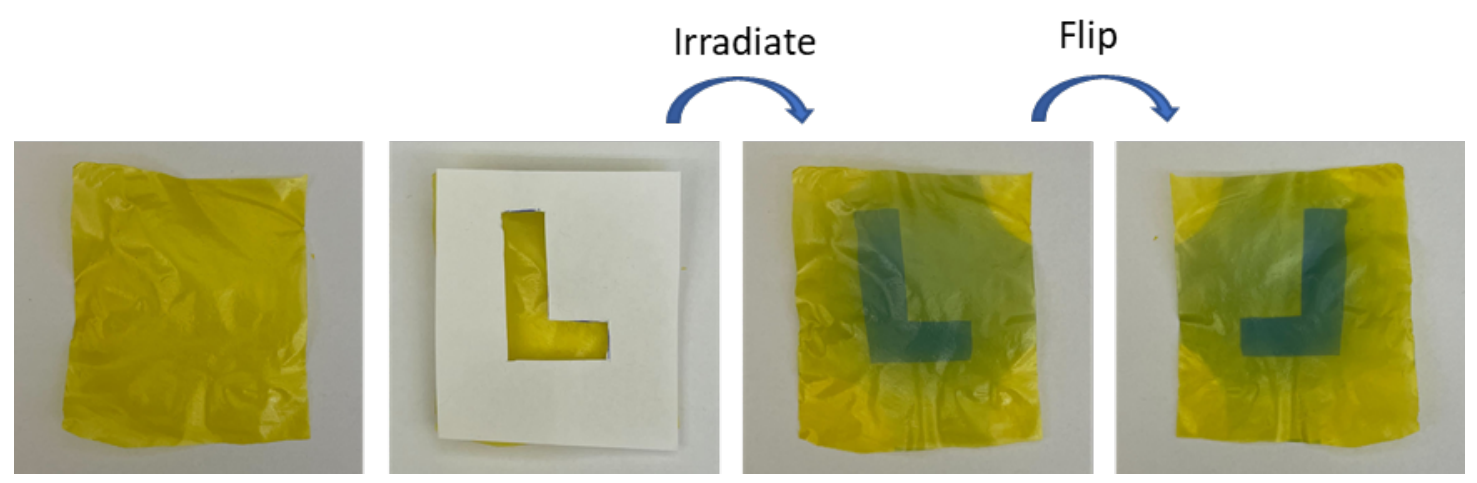

Figure S9: Photographs showing that light irradiation of a $\mathrm{V}(\mathrm{V})$ chitosan pectin film is able to penetrate fully through the film, where the irradiated pattern can be seen on both sides of the film 